\title{
PLGA nanoparticles as a platform for vitamin D-based cancer therapy
}

\author{
Maria J. Ramalho, Joana A. Loureiro, Bárbara Gomes, Manuela F. Frasco, \\ Manuel A. N. Coelho and M. Carmo Pereira*
}

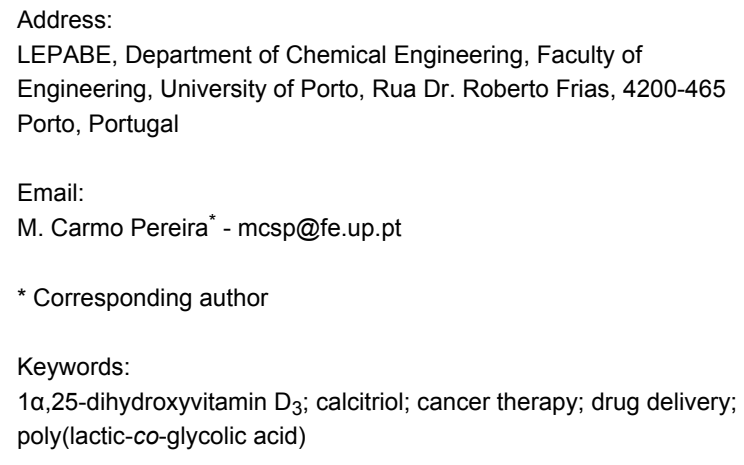

\author{
Beilstein J. Nanotechnol. 2015, 6, 1306-1318. \\ doi:10.3762/bjnano.6.135 \\ Received: 03 March 2015 \\ Accepted: 21 May 2015 \\ Published: 12 June 2015 \\ Associate Editor: K. Koch \\ (c) 2015 Ramalho et al; licensee Beilstein-Institut. \\ License and terms: see end of document.
}

\begin{abstract}
Poly(lactic-co-glycolic acid) (PLGA) nanoparticles were studied as drug delivery vehicles for calcitriol, the active form of vitamin $\mathrm{D}_{3}$. In vitro effects of calcitriol encapsulated in PLGA nanoparticles were evaluated with respect to free calcitriol on human pancreatic cell lines, S2-013 and hTERT-HPNE, and the lung cancer cell line A549. Encapsulated calcitriol retained its biological activity, reducing the cell growth. Cytotoxicity assays demonstrated that encapsulation of calcitriol enhanced its inhibitory effect on cell growth at a concentration of $2.4 \mu \mathrm{M}$ for the S2-013 cells (91\%) and for A549 cells (70\%) comparared to the free calcitriol results. At this concentration the inhibitory effect on nontumor cells (hTERT-HPNE) decreased to $65 \%$. This study highlights the ability of PLGA nanoparticles to deliver vitamin $\mathrm{D}_{3}$ into cancer cells, with major effects regarding cancer cell cycle arrest and major changes in the cell morphological features.
\end{abstract}

\section{Introduction}

Vitamin $\mathrm{D}_{3}$, a secosteroid hormone produced through sunlight exposure [1], can be found with different chemical structures: calciol or cholecalciferol, calcidiol and calcitriol. Cholecalciferol is inert and must be metabolized in the liver and the kidney through two hydroxylation processes in order to be converted into its active form, calcitriol [2]. Calcitriol acts like classical steroid hormones, binding to vitamin D receptor (VDR) and targeting gene expression via both genomic and nongenomic pathways [1]. Although known as an important regulator of calcium homeostasis and bone mineralization [3], several studies support that vitamin D also plays a major role in tumor pathogenesis, progression and therapy [2]. Calcitriol is also regarded as a cancer chemopreventive agent due to promising epidemiological, preclinical and clinical findings [4]. The protective role of vitamin $\mathrm{D}$ against cancer has been mainly attributed to its anti-inflammatory activity [5]. 
The antineoplastic activity of calcitriol in pancreatic and lung cancer is well established, as reported by various in vitro and in vivo studies [6-13]. Several pathways by which calcitriol may prevent, treat or stop tumor growth have been described [1,2]. However, calcitriol exhibits antitumoral activity only in supraphysiological doses associated with a high risk of hypercalcemia [14]. Also, vitamin $\mathrm{D}_{3}$ is sensitive to many external and environmental factors such as temperature changes, oxygen pressure, light, etc. that may affect the molecular structure and the associated functionality [15]. Studies also show that more than $75 \%$ of vitamin D intake is catabolized and excreted before being converted to its active form or before its storage. In addition to these drawbacks, the clinical use of vitamin $\mathrm{D}_{3}$ exhibits other concerns as its short half-life in the bloodstream [16] and first-pass effect [17].

Despite multiple the medicinal benefits of calcitriol, the discussed drawbacks continue to be highlighted as major challenges in developing formulations for clinical use. To overcome some of these limitations, we propose drug delivery systems for new calcitriol formulations. These nanosystems, namely nanoparticles (NPs), must meet several requirements such as biocompatibility, biodegradability, mechanical strength, FDA approval and low synthesis complexity. One of the most attractive candidates is poly(lactic-co-glycolic acid) (PLGA), which is a copolymer of poly(lactic acid) (PLA) and poly(glycolic acid) (PGA) $[18,19]$. We expect that vitamin $\mathrm{D}_{3}$ encapsulation in these polymeric NPs will increase bioavailability by preventing drug degradation before administration, increasing the half-life of vitamin $\mathrm{D}_{3}$ in the bloodstream, avoiding the first-pass effect and circumventing the multidrug resistance (MDR) problem [18]. Also it is well documented that PLGA NPs are efficiently internalized by targeted cells, increasing intracellular drug delivery [20], allowing a sustained and controlled drug release over time [19]. Moreover, PLGA NPs could offer selective drug delivery to tumor tissue either by passive targeting with the enhanced permeability and retention effect (EPR) [18] or by active targeting, using functionalized NPs [21]. Thus, the drug toxicity on healthy cells could be reduced, increasing NPs accumulation in the target tissues [19].

Although several studies on vitamin $\mathrm{D}_{3}$ encapsulation for food fortification have been conducted, very few works reported the use of nanocarriers for vitamin $\mathrm{D}_{3}$ delivery towards cancer treatment. Vitamin $\mathrm{D}_{3}$ vectorisation to guarantee specific action on malignant cells that avoids side effects such as hypercalcemia has been proposed. Nguyen et al. developed a formulation based on poly(vinyl neodecanoate-crosslinked-ethyleneglycol dimethacrylate) microspheres with a size of about $35 \mu \mathrm{m}$ [22]. In this project, the authors used cholecalciferol as a drug model for calcitriol. They demonstrated that their cholecalcif- erol-loaded microspheres are biocompatible, allowed for controlled and sustained release, and increased the efficiency of the therapy [22]. A few years later, Almouazen et al. developed a formulation using PLA nanoparticles of about $200 \mathrm{~nm}$ [14]. This study proved that PLA nanocapsules are a suitable choice for controlled delivery of antineoplastic agents, namely the nanoencapsulated calcidiol induced a significant growth inhibition when compared to free calcidiol, and the PLA NPs enhanced the intracellular delivery of vitamin in breast cancer cells [14]. In another work, Bonor et al. [23] developed calcitriol-conjugated quantum dots to analyze calcitriol distribution and dynamics in mouse myoblast cells. The authors concluded that the designed tool is suitable for imaging drug-tumor interactions and to deliver drugs to tumors and metastasized sites [23].

The aim of the present study was to evaluate the capacity of PLGA NPs to encapsulate and to deliver calcitriol, the active form of vitamin $\mathrm{D}_{3}$, into human cells. PLGA NPs were prepared as nanocarriers, and for the purpose of formulating and characterizing the designed system, the inactive form of vitamin $\mathrm{D}_{3}$, cholecalciferol, was also used as drug model along with calcitriol. We evaluated the effect of calcitriol-loaded PLGA NPs on normal and tumor cells in terms of cell growth, cell cycle arrest and morphological changes.

\section{Results}

\section{Nanoparticle physicochemical properties}

PLGA NPs were prepared by a single emulsion solvent evaporation method and stabilized with Pluronic ${ }^{\circledR} F 127$. The obtained results for mean the diameter, polydispersity index (PDI) and zeta potential for the unloaded PLGA NPs are shown in Table 1. According to the literature, the PLGA NPs size is found to be in the range of 100 to $250 \mathrm{~nm}$ [20]. The prepared unloaded NPs are within the expected range, exhibiting a mean diameter of $172 \pm 4 \mathrm{~nm}$, and presenting a zeta potential value of $-38 \mathrm{mV}$ : negative, as expected, due to their carboxylic end groups (Table 1).

The single emulsion solvent evaporation method allowed the encapsulation of vitamin $\mathrm{D}_{3}$ in the PLGA NPs. The obtained results for the mean diameter, PDI, zeta potential, encapsulation efficiency and loading capacity values for the PLGA NPs loaded with cholecalciferol and calcitriol are also shown in Table 1. The size of the vitamin-loaded NPs (187 $\pm 7 \mathrm{~nm}$ for cholecalciferol-loaded, and $186 \pm 3 \mathrm{~nm}$ for calcitriol-loaded) increased significantly $(p<0.05)$ in comparison to unloaded PLGA NPs (172 $\pm 4 \mathrm{~nm})$. Moreover, the mean size values were not significantly different between cholecalciferol and calcitriol-loaded NPs $(p>0.05)$. The prepared systems exhibited a narrow size distribution $(\mathrm{PDI} \leq 0.1)$. TEM analysis 
Table 1: Physicochemical features of unloaded, cholecalciferol and calcitriol-loaded PLGA NPs. The data is presented as the mean \pm SD $(n=3)$

\begin{tabular}{|c|c|c|c|c|c|}
\hline PLGA NPs & Mean diameter (nm) & PDI & Zeta potential (mV) & $\mathrm{EE}(\%)$ & LC $(\%)$ \\
\hline Unloaded & $172 \pm 4$ & $0.064 \pm 0.040$ & $-38 \pm 3$ & - & - \\
\hline Cholecalciferol-loaded & $187 \pm 7$ & $0.110 \pm 0.065$ & $-29 \pm 3$ & $83 \pm 2$ & $8.3 \pm 0.2$ \\
\hline Calcitriol-loaded & $186 \pm 3$ & $0.056 \pm 0.025$ & $-34 \pm 4$ & $57 \pm 8$ & $5.7 \pm 0.9$ \\
\hline
\end{tabular}

revealed spherical- and uniform-shaped PLGA nanoparticles, as shown in Figure 1. The diameter of the nanoparticles revealed by this method varies between approximately 170 and $190 \mathrm{~nm}$, which is consistent with the size measurements by DLS.

The absolute value of the zeta potential significantly decreased from 38 in unloaded PLGA NPs to 29 in cholecalciferol-loaded NPs $(p<0.05)$. The decrease to $34 \mathrm{mV}$ observed for calcitriolloaded NPs was not significant $(p>0.05)$. Moreover, zeta potential values were not significantly different between cholecalciferol and calcitriol-loaded NPs $(p>0.05)$.

The obtained results for the encapsulation efficiency (EE) for both encapsulated forms of vitamin $\mathrm{D}_{3}$ are presented in Table 1 . The attained values significantly decrease $(p<0.05)$ from $83 \pm 2 \%$ for cholecalciferol to $57 \pm 8 \%$ for calcitriol. The loading capacity of PLGA NPs was also evaluated, exhibiting significant differences in the determined values $(p<0.05)$ of $8.3 \pm 0.2 \%$ for cholecalciferol-loaded NPs and $5.7 \pm 0.9 \%$ for the NPs loaded with calcitriol (Table 1). The yield of the PLGA NPs production process reached values of $57 \pm 4 \%(n=3)$.

Calcitriol-loaded PLGA nanoparticles stability studies were carried out at $4{ }^{\circ} \mathrm{C}$ over 60 days. The NPs showed a mean size of $186 \pm 3 \mathrm{~nm}$, which remained constant over time, exhibiting a mean $d / d_{0}$ value of 1.0 for approximately 50 days. The $d / d_{0}$ parameter refers to the ratio between mean diameter at each set time measurement during the 50 days and the initial NP mean diameter. After this period, the $d / d_{0}$ ratio increased to 6.4 .

The obtained results for the mean diameter, PDI and zeta potential, presented in Table 2, allowed for the assessment of aggre-
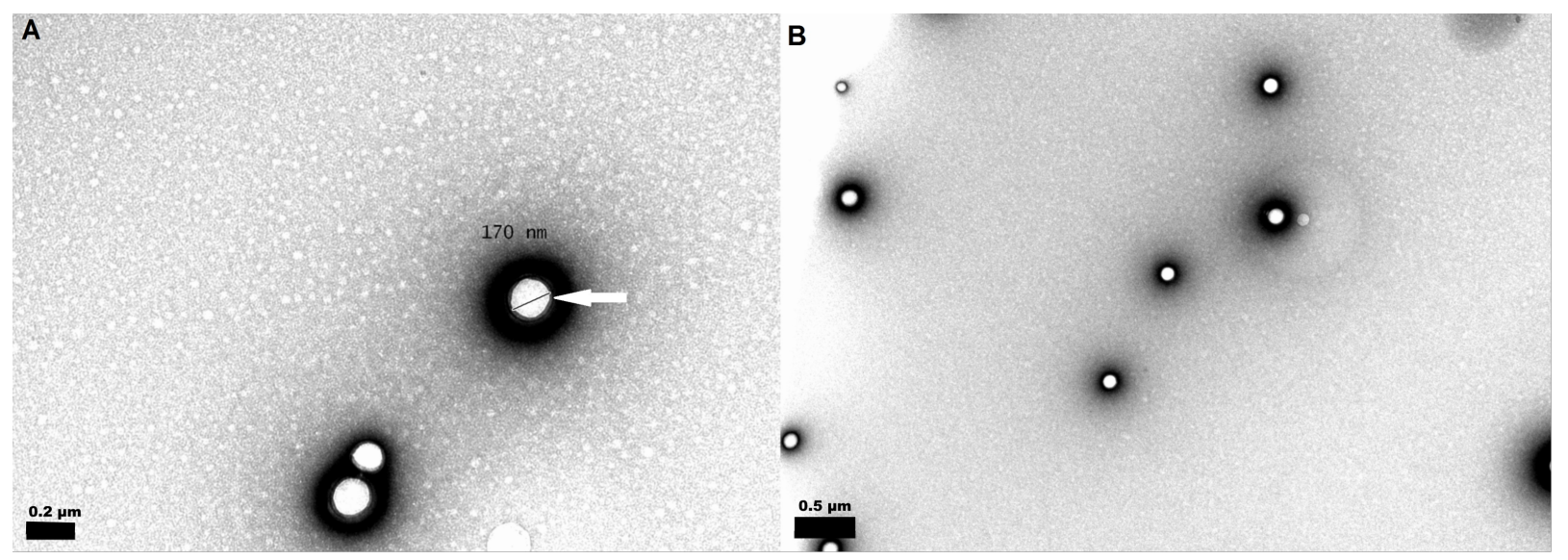

Figure 1: TEM images of (a) unloaded PLGA nanospheres, scale bar: $200 \mathrm{~nm}$; and (b) loaded PLGA nanospheres, scale bar: 500 nm. The white arrow indicates the pluronic layer surrounding the PLGA NP.

Table 2: PLGA NPs physicochemical characterization after freeze-drying experiments, with and without a cryoprotective agent. The mean size variation is expressed in terms of the ratio $d / d_{0}$, where $d$ is mean diameter after freeze-drying and $d_{0}$ is the initial NP mean diameter. The data is presented as the mean $\pm \operatorname{SD}(n=3)$.

\begin{tabular}{cccccc}
\multicolumn{2}{c}{ Calcitriol-PLGA NPs } & Mean diameter $(\mathrm{nm})$ & $d / d_{0}$ & PDI & Zeta potential $(\mathrm{mV})$ \\
\hline \multirow{2}{*}{ Before freeze-drying } & & $186 \pm 3$ & - & $0.056 \pm 0.025$ & $-34 \pm 4$ \\
& Without cryoprotection & $1591 \pm 167$ & 8.55 & $0.613 \pm 0.370$ & $-31 \pm 1$ \\
After freeze-drying & Sucrose 1\% & $193 \pm 1$ & 1.04 & $0.096 \pm 0.028$ & $-29 \pm 3$
\end{tabular}


gation or modification of the PLGA NPs properties after freezedrying.

The NP PDI values and mean diameter significantly increased from $186 \pm 3 \mathrm{~nm}$ to $1591 \pm 167 \mathrm{~nm}(p<0.05)$ after lyophilization without the cryoprotectant agent (Table 2), showing that the freeze-drying process caused PLGA NP aggregation, resulting in high polydispersity. No significant changes $(p>0.05)$ were observed for the zeta potential values. Hence, it is possible to conclude that these PLGA NPs are not able to overcome the stress caused by the lyophilization process, leading to their destabilization and further aggregation. However, these results also demonstrated that $1 \% \mathrm{w} / \mathrm{v}$ sucrose preserves particle integrity after reconstitution of lyophilized PLGA nanoparticles, yielding no significant changes in the mean diameter $(p>0.05)$. However, the zeta potential values suffer a decrease in the presence of sucrose $(p>0.05)$. This could be explained by sucrose adsorption on the NPs surface.

\section{Calcitriol release from the PLGA nanoparticle}

The release of calcitriol entrapped in PLGA NPs was carried out in PBS $\left(0.01 \mathrm{M}, \mathrm{pH} 7.4\right.$ at $\left.37{ }^{\circ} \mathrm{C}\right)$ and the results are presented in Figure 2.

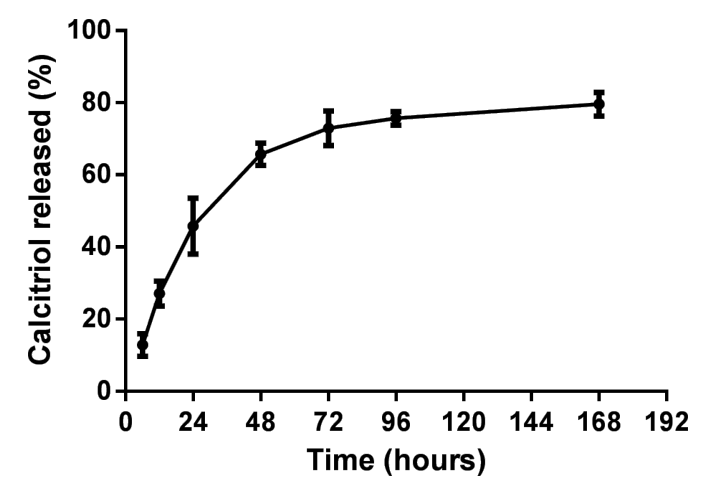

Figure 2: In vitro release profile of calcitriol from PLGA NPs in PBS $(0.01 \mathrm{M}, \mathrm{pH} 7.4)$ at $37^{\circ} \mathrm{C}$. The data is represented as the mean $\pm \mathrm{SD}$ $(n=3)$.

The prepared PLGA NPs exhibited an initial rapid release, followed by a slower, sustained release. As Figure 2 shows, calcitriol released at $24 \mathrm{~h}$ was around $46 \%$. This initial rapid release might be attributed to the release of the surfaceadsorbed vitamin. The calcitriol entrapped in the polymeric matrix of the NP was released later and in a more controlled manner, reaching a quasi-plateau between 96 and $168 \mathrm{~h}$. The plateau represented a release of about $4 \%$ of the encapsulated calcitriol in this period. After $168 \mathrm{~h}$, the total calcitriol released was around $80 \%$. The control sample showed that calcitriol remained stable at release conditions throughout the experiment period.

\section{Cellular uptake of PLGA NPs and calcitriol- induced morphological changes}

The internalization of fluorescent C6-calcitriol-PLGA NPs by S2-013, hTERT-HPNE and A549 cells was evaluated by confocal microscopy. Counterstaining of the cell nuclei was performed with DAPI and the acidic compartments (including endosomes and lysosomes) with LysoTracker ${ }^{\mathrm{TM}}$ Red. The obtained images are presented in Figure 3.

As seen in Figure 3A,D, nontreated pancreatic cells exhibit an intense green color that masks the red color of the lysotracker for lysosomes, despite not having been treated with C6. This fact is justified because both cell lines exhibited autofluorescence in the same emission spectrum as C6 and lysotracker. Lung carcinoma cells did not exhibit this intense autofluorescence, therefore allowing the visualization of the NP uptake (Figure 3G). As shown in Figure 3H, after $2 \mathrm{~h}$ of incubation, the nanoparticles were internalized by A549 cells. It is also possible to observe some colocalization of C6-PLGA NPs with the redstained late endosomes or lysosomes (yellow color, in Figure $3 \mathrm{H}$ ). Quantitative analysis with the ImageJ JACoP "colocalization finder" plug-in was used for colocalization assessment of the NPs with LysoTracker Red in the lysosomes of A549 cells [24]. The statistical method provides the Pearson coefficient $(r)$, which varies between -1 (anti-colocalization) and +1 (total colocalization) and reflects the unambiguous colocalization of two fluorescent probes [25]. The Pearson correlation coefficient for A549 cells significantly decreased from $0.7 \pm 0.1$ for a $2 \mathrm{~h}$ treatment to $0.4 \pm 0.1$ and $0.14 \pm 0.06$ for $48 \mathrm{~h}$ and $72 \mathrm{~h}$ treatment, respectively $(p<0.05)$. This decrease over time suggests an endo-lysosomal escape, with most of the PLGA NPs localized in the cytoplasm after $72 \mathrm{~h}$, as exhibited in Figure 3I. Due to the intense cell autofluorescence, it was not possible to determine the Pearson coefficient for both pancreatic cell lines. However it was possible to observe yellow dots in the S2-013 and hTERT-HPNE cells incubated with C6-calcitriol-PLGA NPs for $2 \mathrm{~h}$ (Figure 3B,E). We were able to observe this colocalization due to the higher green fluorescence intensity of C6-calcitriol-PLGA NPs. The presence of these yellow dots is reduced in cells incubated with C6-calcitriol-PLGA NPs for $72 \mathrm{~h}$ (Figure 3C,F), due to the endo-lysosomal escape, with most of the PLGA NPs localized in the cytoplasm. However, it is not possible to distinguish this due to autofluorescence in the pancreatic cells and extensive morphological changes. As can be seen in Figure 3C,F, pancreatic cells treated with calcitriol-PLGA NPs at $2.4 \mu \mathrm{M}$ for $72 \mathrm{~h}$ displayed major changes in shape when compared to untreated 


\section{Control}
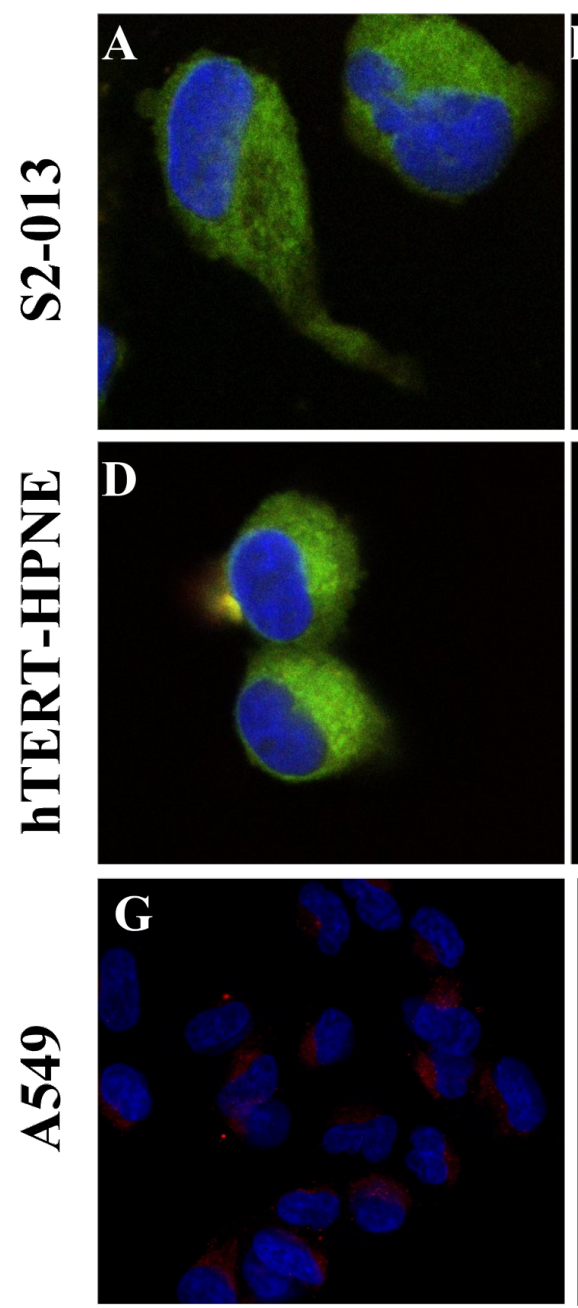

$2 \mathbf{h}$ incubation
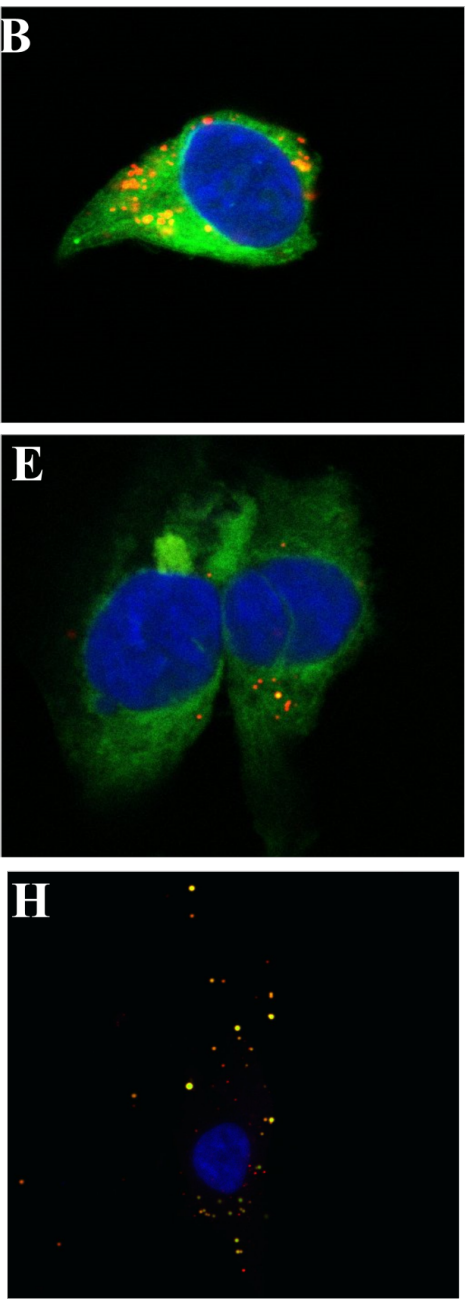

$72 \mathrm{~h}$ incubation
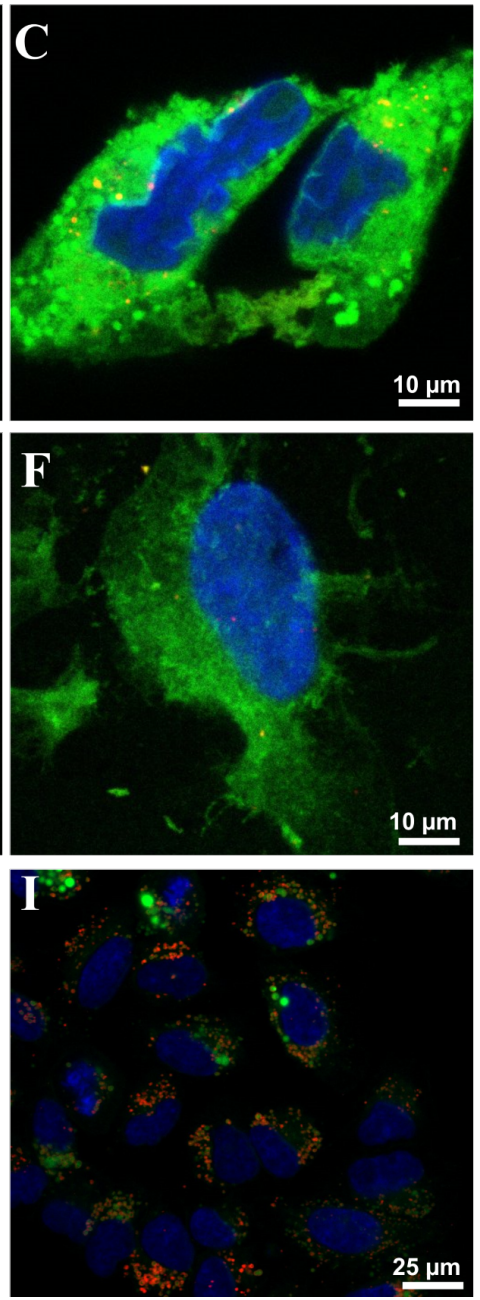

Figure 3: Confocal laser scanning microscopy images of human cells treated with calcitriol entrapped in C6-PLGA NPs. S2-013 cells: (A) control cells; cells after (B) 2 and (C) 72 h of incubation with C6-calcitriol-PLGA NPs. hTERT-HPNE cells: (D) control cells; cells after (E) 2 and (F) 72 h of incubation with C6-calcitriol-PLGA NPs. A549 cells: (G) control cells; cells after (H) 2 and (I) 72 h of incubation with C6-calcitriol-PLGA NPs. The blue color represents the nuclei and the yellow color represents the colocalization of PLGA NPs with the late endosomes/lysosomes. Scale bar: $10 \mu \mathrm{m}$ for images $\mathrm{A}-\mathrm{F}$, and $25 \mu \mathrm{m}$ from $\mathrm{G}-\mathrm{I}$.

growing cells (Figure 3A,D). In contrast, the control cells display rounded shapes, and the treated cells exhibited enlarged and flattened irregular shapes and multiple or enlarged nuclei, in both cell lines. The observed morphological features are consistent with senescence phenomena.

\section{Cell growth inhibition by calcitriol-loaded NPs}

The in vitro cytotoxic effects on three different human cell lines, hTERT-HPNE, S2-013 and A549, after treatment with calcitriol entrapped into the PLGA NPs were assessed relative to free calcitriol in terms of cell growth. Treatment with $0.1 \%$ ethanol and unloaded PLGA NPs during $72 \mathrm{~h}$ had no signifi- cant effect on the cell growth for the used cell lines (data not showed). These results prove that PLGA nanoparticles are biocompatible.

The effect of calcitriol at concentrations from 0.005 to $3.2 \mu \mathrm{M}$ was tested with concentrations of PLGA in the range of $0.1 \mu \mathrm{g} \mathrm{mL}^{-1}$ to $50 \mu \mathrm{g} \mathrm{mL}^{-1}$. The efficacy of calcitriol-loaded NPs in comparison to free calcitriol was also evaluated. Due to its known short half-life in the cell culture medium, an assay with S2-013 cells was performed for $48 \mathrm{~h}$ to compare cell survival between single-addition and daily-renewed calcitriol. As shown in Figure 4A, the poor stability of calcitriol is re- 

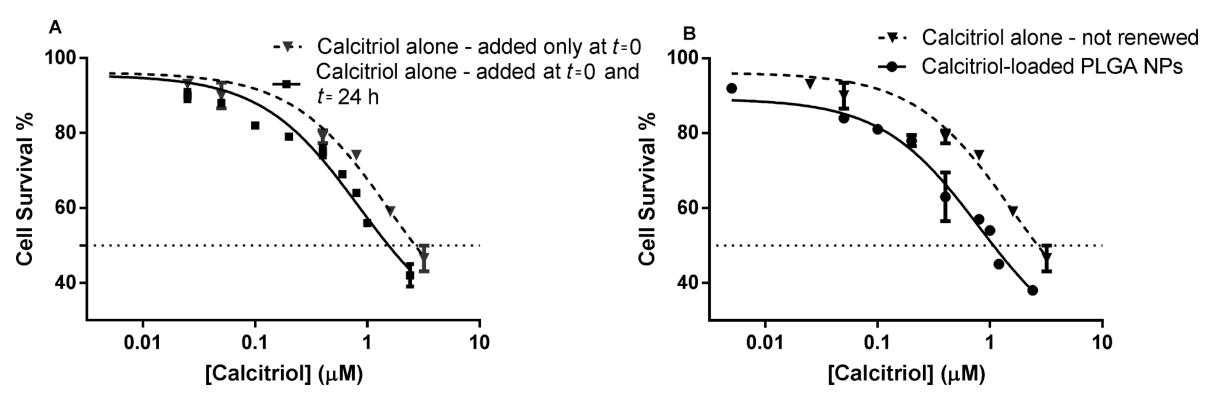

Figure 4: Effects of calcitriol after $48 \mathrm{~h}$ treatment on S2-013 cell survival, determined by SRB assay. (A) Comparison between a single-addition and daily renewal of calcitriol; (B) Comparison between calcitriol free (single-addition) and entrapped in PLGA NPs. Free calcitriol, added only at $t=0$, is represented with triangles and a dotted line; free calcitriol, added at $t=0$ and $t=24 \mathrm{~h}$, is represented with squares and a solid line; and calcitriol-NPs with spheres and a solid line.

flected by reduced toxicity when cells are treated with a single addition for $48 \mathrm{~h}$. For the same range of concentrations, singleadded calcitriol at $t=0$ shows a decreased in vitro antitumor activity when compared to daily-renewed calcitriol, resulting in significantly different $(p<0.05) 48 \mathrm{~h} \mathrm{IC}_{50}$ values of $2.19 \mu \mathrm{M}$ and $1.51 \mu \mathrm{M}$, respectively. Thus, all cytotoxicity assays with free calcitriol compared to calcitriol-loaded NPs were renewed daily.

Both free and encapsulated calcitriol exhibited a concentrationrelated decrease in cell growth and survival of the human cell lines (Figure 5, Supporting Information File 1, respectively). We observed an advantage of PLGA NPs, in that calcitriol-NPs are more efficient than free calcitriol with regards to cell growth inhibition (Figure 5). For instance, incubation for $72 \mathrm{~h}$ with $3.2 \mu \mathrm{M}$ nanoencapsulated calcitriol reduced the cell growth of lung carcinoma cells to about $20 \%$ compared to $45 \%$ when free calcitriol was administered (Figure 5F). Thus, drug delivery with this polymeric system improves calcitriol antiproliferative activity, resulting in significantly $(p<0.05)$ lower $\mathrm{GI}_{50}$ values (Table 3). In a $48 \mathrm{~h}$ assay, free calcitriol inhibits the S2-013 cell growth by $50 \%$ when its concentration is $0.78 \mu \mathrm{M}$ (renewed daily, total of 2 administrations), which is higher than equivalent $0.53 \mu \mathrm{M}$ calcitriol of the loaded NPs (added only at $t=0$ ) with the same effect (Table 3 ).

Still, it is important to highlight that due to the short calcitriol half-life in the cell culture medium, the presented free drug
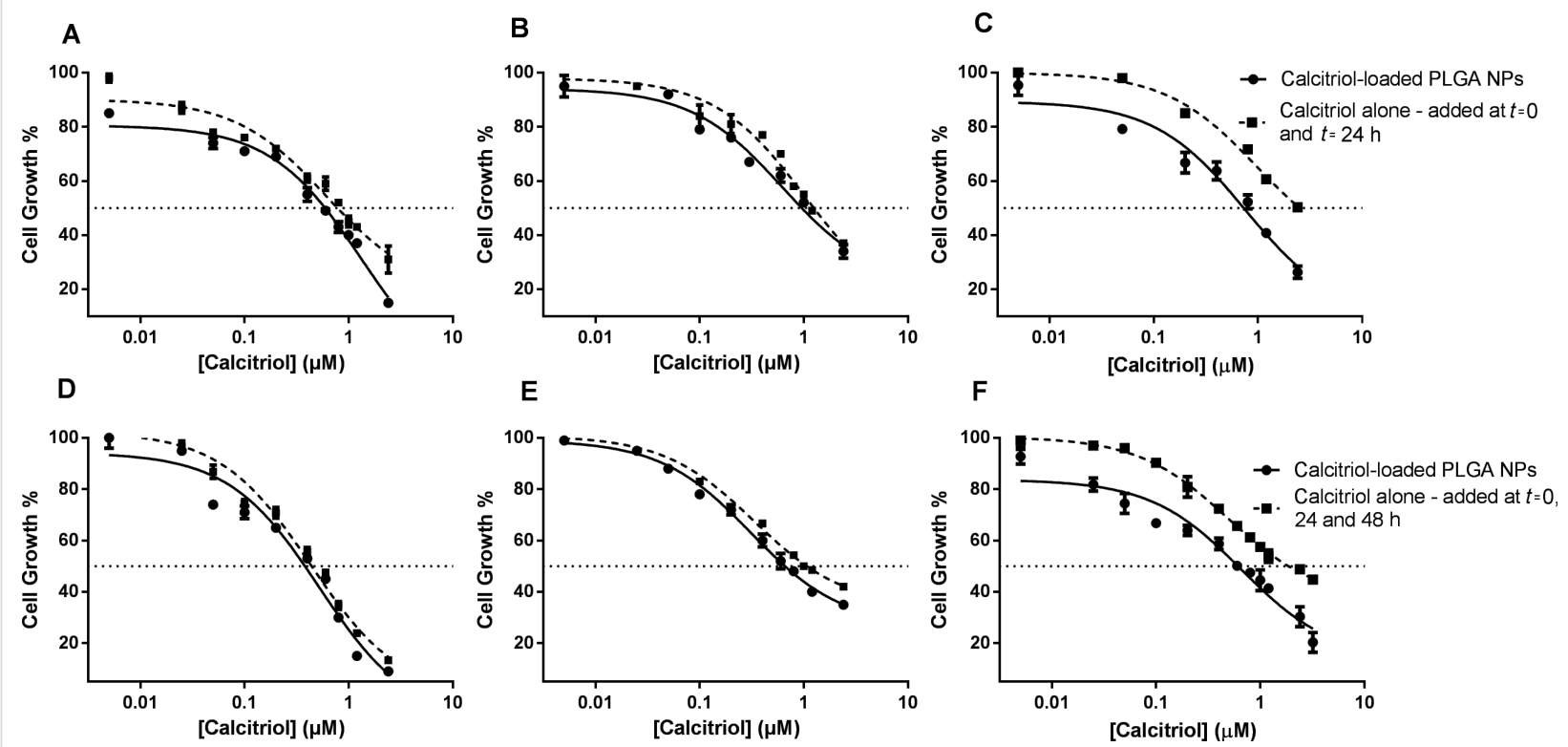

Figure 5: Cytotoxic effects of calcitriol free and calcitriol entrapped in PLGA NPs after $48 \mathrm{~h}(\mathrm{~A}-\mathrm{C})$ and $72 \mathrm{~h}$ (D-F) treatment on the cell growth of three human cell lines, (A,D) S2-013, (B,E) hTERT-HPNE and (C,F) A549, determined by a SRB assay. Free calcitriol is represented with squares and a dotted line; and calcitriol-NPs with spheres and a solid line. 
Table 3: Cytotoxic effects of calcitriol on the growth of cell lines, S2-013, hTERT-HPNE and A549, respectively. The results are expressed as GI 50 (the concentration necessary to inhibit cell growth to $50 \%$ ) at 48 and $72 \mathrm{~h}$ of exposure with free calcitriol and entrapped calcitriol in PLGA NPs by SRB assay.

\begin{tabular}{|c|c|c|c|c|}
\hline & & \multicolumn{3}{|c|}{$\mathrm{GI}_{50}(\mu \mathrm{M})$} \\
\hline & & S2-013 & hTERT-HPNE & A549 \\
\hline \multirow{2}{*}{$48 \mathrm{~h}$ assay } & Calcitriol (renewed daily) & $0.78 \pm 0.01$ & $1.25 \pm 0.01$ & $2.04 \pm 0.18$ \\
\hline & Calcitriol-PLGA NPs & $0.53 \pm 0.02$ & $1.12 \pm 0.04$ & $1.03 \pm 0.16$ \\
\hline \multirow{2}{*}{$72 \mathrm{~h}$ assay } & Calcitriol (renewed daily) & $0.48 \pm 0.01$ & $1.08 \pm 0.01$ & $1.90 \pm 0.25$ \\
\hline & Calcitriol-PLGA NPs & $0.43 \pm 0.01$ & $0.83 \pm 0.02$ & $0.49 \pm 0.10$ \\
\hline
\end{tabular}

concentrations were added daily, unlike entrapped calcitriol, which was loaded in the NPs only once at time $t=0$. Thus, despite that the NPs themselves already show an advantage compared to free, daily renovated calcitriol, if the comparison was made between loaded NPs and single-addition, free calcitriol, that advantage would be much more evident as demonstrated by Figure 4B.

For the different cell types, treatment with encapsulated calcitriol for $72 \mathrm{~h}$ showed significantly more deleterious effects than $48 \mathrm{~h}$ treatment, resulting in lower $\mathrm{GI}_{50}$ values for the $72 \mathrm{~h}$ assay $(p<0.05)$ (Table 3$)$. Also, it is quite relevant to analyze and compare the effect of free calcitriol and loaded NPs on the different cell lines. The results shown in Figure 5 demonstrated that the deleterious calcitriol effect was significantly $(p<0.05)$ higher in the pancreatic cancer cell line, S2-013. GI 50 values for S2-013 cells are significantly lower than for hTERT-HPNE and A549 cells (Table 3$)(p<0.05)$. Although the NPs show potential for the drug's effect on the hTERT-HPNE cell line, likewise as for the pancreatic tumor cells, hTERT-HPNE cells show more resistance to the vitamin's toxicity, whether calcitriol is encapsulated or not. For instance, while $0.005 \mu \mathrm{M}$ calcitriol loaded in PLGA NPs reduced the cell growth of the S2-013 cell line to about $80 \%$ after $48 \mathrm{~h}$, at the same concentration, calcitriol-PLGA NPs do not show toxicity in the hTERT-HPNE cell line (Figure 5A,B). The lung carcinoma cell line exhibited the lowest sensitivity to the free calcitriol's antiproliferative activity among the used cell lines $(p<0.05)$. However, this was not true for the encapsulated form of calcitriol. This was the cell line where the encapsulation of calcitriol in NPs proved to be more advantageous.

\section{Cell cycle arrest by calcitriol-loaded PLGA NPs}

To assess whether the cytotoxic effects of calcitriol are due to cell cycle inhibition, cell cycle analysis by flow cytometry was performed in propidium iodide (PI)-stained S2-013, hTERTHPNE and A549 cells after treatment with free calcitriol and calcitriol-loaded PLGA NPs at $1.2 \mu \mathrm{M}$ for $72 \mathrm{~h}$. PI counterstaining was used for DNA quantification. The differences in the DNA content between the cell population allowed the cell cycle distribution to be studied [26]. The attained results are presented in Figure 6.

As Figure 6A shows, cell cycle analysis demonstrated a significant accumulation of both pancreatic cell lines in the $G_{0} / G_{1}$ phase after exposure to calcitriol $(p<0.05)$. This accumulation was associated to a concomitant decrease in the $\mathrm{S}$ or/and $\mathrm{G}_{2} / \mathrm{M}$ phases (Figure 6B,C). Additionally, the observed changes on the cell cycle distribution between control A549 cells and A549 cells treated with free calcitriol for $72 \mathrm{~h}$ were not significant $(p>0.05)$. These results are in agreement with the proliferation studies, where the A549 cell line exhibited the lowest sensitivity to the calcitriol antiproliferative effect. As it is also shown in Figure 6A, encapsulation of calcitriol in PLGA NPs enhanced the calcitriol growth inhibition, inducing a signifi-
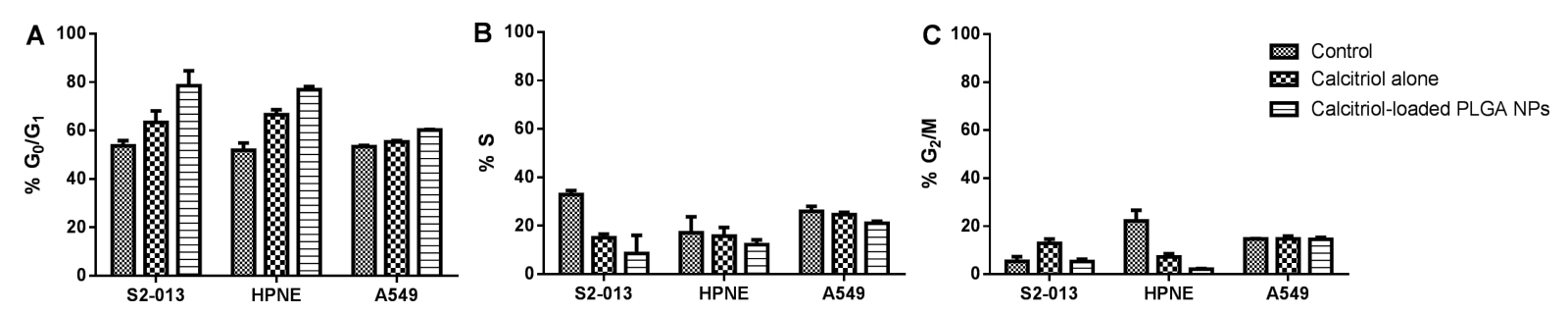

Figure 6: Cell cycle distribution of S2-013, hTERT-HPNE and A549 cells treated for $72 \mathrm{~h}$ with free calcitriol and calcitriol entrapped in PLGA NPs. The graphs show the percentage of cells in (A) $G_{0} / G_{1}$, (B) $S$ and (Cc) $G_{2} / M$ phases. The data is represented as the mean $\pm S D(n=3)$. 
cantly increased accumulation of cells in the $G_{0} / G_{1}$ phase, in the three different cell lines, compared to free calcitriol $(p<0.05)$. The cell cycle arrest in the treated cell lines was not accompanied by significant changes in the amount of sub- $\mathrm{G}_{1}$ cells (data not shown), relative to the control cells, indicating little apoptosis after $72 \mathrm{~h}$ treatment with free and entrapped calcitirol. The sub- $\mathrm{G}_{1}$ group represents the apoptotic cells with fractional DNA, which appear as cells with hypodiploid DNA content [27]. These data suggest that calcitriol antiproliferative effects, observed in cytotoxicity assays, could occur in consequence of cell cycle arrest.

\section{Discussion}

The antineoplastic activity of calcitriol, the active form of vitamin $\mathrm{D}_{3}$, has been well documented both in vitro and in vivo. Despite calcitriol clinical application, it exhibits several limitations. This work addresses the ability of PLGA NPs to overcome some of the described drawbacks. PLGA nanoparticles were formulated as promising delivery systems to improve the therapeutic potential of calcitriol. The PLGA NPs were prepared by a single emulsion solvent evaporation method and stabilized with Pluronic ${ }^{\circledR}$ F127. The prepared NPs exhibited mean diameters smaller than $200 \mathrm{~nm}$ and negative zeta potential. The observed increase in the mean size with the encapsulation of both forms of vitamin, as compared with unloaded NPs, was anticipated. This effect was reported in studies arguing that the drug causes an expansion of the polymeric matrix, increasing the particle size [28]. The decrease in zeta potential values with the encapsulation of both forms of vitamin could be attributed to vitamin adsorption on the PLGA NPs surface. As already reported, the drug adsorbed on the PLGA NP surface exerts a masking effect of the superficial carboxylic groups, reducing the effective NP charge [28]. The NP stability is a result of electrostatic forces due to the PLGA carboxylate groups at the NP surface, and the surfactant behavior that also plays a crucial role in maintaining nanosuspension stabilization. During particle formation, the Pluronic ${ }^{\circledR} \mathrm{F} 127$ is adsorbed onto the NP surface, providing steric and thermodynamic stabilization (Figure 1, white arrow) [29].

Both forms of vitamin $\mathrm{D}_{3}$ were used for the formulation of the nanocarrier system and variations in the encapsulation efficiency and loading capacity were noticed. The observed differences may be based on their chemical structure, since calcitriol has two extra hydroxy groups and is less hydrophobic than cholecalciferol. Thus, its partition into the aqueous phase may occur during the NP preparation, resulting in lower EE and LC values [14]. The EE and $L C$ values achieved are in accordance with our experience with other hydrophobic drugs [30] and other results reported in literature [20]. The prepared nanoparticles remained stable under storage conditions for several weeks.
The nanoparticle emulsions were successfully lyophilized by the addition of sucrose to increase the shelf-life time. The choice of sucrose as the cryoprotective agent was justified by the previous work of Holzer et al., where it was proven that this is a well-suited cryoprotectant [31].

PLGA NPs tend to exhibit a biphasic release pattern, characterized by an initial rapid release, followed by a slower sustained release [19]. As expected, the NPs exhibited a rapid release in the first $24 \mathrm{~h}$ due to the release of calcitriol adsorbed onto the NP surface. The sustained release over the next $168 \mathrm{~h}$ could be attributed to the diffusion of vitamin from the NP core into the release medium. In aqueous medium, PLGA suffers biodegradation by hydrolytic cleavage of its ester linkages into monomers. During hydrolysis, acidic degradation products accumulate inside the PLGA NPs and are responsible for reaction autocatalysis. The hydrolytic breakdown also causes the formation of pores, allowing the release of oligomers and monomers, resulting in bulk erosion [32]. As the NP degradation is slow, the release between 48 and $168 \mathrm{~h}$ may depend mainly on vitamin diffusion through the polymeric matrix and matrix erosion [19,33].

Human cell lines, S2-013, hTERT-HPNE and A549, were selected to evaluate the antiproliferative potential of calcitriolloaded PLGA NPs. A549 lung carcinoma line proved to be the least sensitive line to the free calcitriol activity. Pelczynska et al. previously reported that A549 is a VDR-negative cell line, only exhibiting VDR expression after incubation with calcitriol, which explains the low sensitivity to the drug [11]. To this date, no work regarding calcitriol activity on the pancreatic cell lines, S2-013 and hTERT-HPNE, was reported. The in vitro proliferation assay showed that the encapsulation of calcitriol enhanced its antiproliferative activity. The efficient cell internalization by an endocytosis mechanism of PLGA NPs and their rapid endolysosomal escape observed in this study could explain the benefits of the drug encapsulation in the NPs. Tahara et al. showed that PLGA NPs are efficiently internalized by A549 cells by an endocytosis mechanism, partially mediated by a clathrin [34], which can explain the NP-enhanced calcitriol activity reported in this work. Therefore, this mechanism of NP internalization avoids calcitriol transport out of cells mediated by P-glycoprotein involved in the MDR problem. It was previously established that after internalization, PLGA NPs suffer a charge change triggered by the acidic medium of late endosome/lysosome. This leads to the destabilization of the endo-lysosomal membrane, allowing the escape of NPs into the cytoplasm [18]. Also, the prepared nanoparticles were stabilized with the Pluronic ${ }^{\circledR} F 127$, known for its ability to overcome MDR by direct inhibition of P-glycoprotein [35]. The obtained results suggest that these PLGA NPs are able to work as cytoplasmic 
delivery vehicles. Also, because calcitriol has a short half-life, its entrapment in PLGA NPs allows vitamin protection, sustained and controlled delivery, thus avoiding drug degradation and inactivation. The sustained and controlled release of the prepared PLGA NPs explains the increased inhibition of cell growth in the $72 \mathrm{~h}$ assay, as compared with the $48 \mathrm{~h}$ assay. We conclude that a longstanding treatment presents more pronounced, deleterious effects since these NPs are able to maintain drug concentrations.

Furthermore, flow cytometry analysis demonstrated that encapsulation of calcitriol in PLGA NPs enhanced the growth inhibition of the human cells by inhibiting the cell cycle progression at the $\mathrm{G}_{1}-\mathrm{S}$ transition, as previously reported [7,12,36,37]. As confocal imaging studies demonstrated, this cell cycle arrest was associated with major changes in the morphological features of the calcitriol-loaded PLGA-NP-treated pancreatic cells, consistent with the senescence phenomena. Senescent cells are described as cells permanently arrested in the cell cycle [38], and it was already reported that calcitriol can trigger cell senescense [39].

\section{Conclusion}

A PLGA NP system was developed for calcitriol delivery. The prepared system is stable under storage conditions for several weeks and was lyophilized to increase its shelf life. The NPs exhibited a rapid release in the first $24 \mathrm{~h}$ followed by sustained release over the following days, after which a diffusion equilibrium between the NPs and release medium occurred. The in vitro cytotoxic studies proved that unloaded PLGA NPs are biocompatible and revealed the toxicity effect of calcitriol against human pancreatic and lung cells. Due to the short calcitriol half-life in the cell culture medium, daily renewal was necessary to maintain its concentration. This results in an increase in the frequency of administration, and consequently, in the increased amount of drug in comparison to calcitriol encapsulated in the PLGA nanoparticles. As a result, the obtained data prove that PLGA NPs enhance calcitriol antineoplastic activity, allowing reduced administration frequency, as well as lower drug dosage, and thus increased drug bioavailability. This work also demonstrated that encapsulation in a nanovehicle enhanced the growth inhibition effect of calcitriol in the treated human cell lines by inducing cell cycle arrest in the $\mathrm{G}_{1}-\mathrm{S}$ phase. This antiproliferative effect was associated with major morphological changes in the treated cells. The obtained results suggest that the lack of growth of the human cells lines upon treatment with free and entrapped calcitriol is a result of a drug-induced senescence. Thus, we can conclude that nanoencapsulation in PLGA NPs may offer a new and potentially effective administration strategy of calcitriol that overcomes the actual limitations such as its low bioavailability.

\section{Experimental Chemicals}

PLGA Resomer ${ }^{\circledR}$ RG503H (50:50; $M_{\mathrm{w}}$ 24,000-38,000), ethyl acetate, Pluronic ${ }^{\circledR} \mathrm{F} 127$, coumarin-6 (C6) $\left(M_{\mathrm{w}} 350.43\right)$, phosphate buffered saline (PBS), acetic acid, sulforhodamine B (SRB), trypan blue, ribonuclease A (RNase) from bovine pancreas $\left(M_{\mathrm{W}} 13,700\right.$; solution of $50 \%$ glycerol $)$, propidium iodide $\left(M_{\mathrm{w}} 668.39\right.$, purity $\left.\geq 94 \%\right)$ and Triton $\mathrm{X}^{\mathrm{TM}}-100$ were purchased from Sigma-Aldrich (St. Louis, MO, USA). Cholecalciferol (vitamin $\mathrm{D}_{3}, M_{\mathrm{w}} 384.65$, purity $\geq 99 \%$ ) was purchased from Alfa Aesar (Karlsruhe, Germany). Calcitriol (Rocaltrol, $M \mathrm{w} 416.64$, purity $\geq 99 \%$ ) was purchased from Selleck Chemicals (Munich, Germany). Uranyl acetate (dehydrate, $424.146 \mathrm{~g} / \mathrm{mol}$ ) was purchased from Electron Microscopy Sciences (Hatfield, UK). Dulbecco's Modified Eagle medium (DMEM) and Roswell Park Memorial Institute medium (RPMI) were acquired from Invitrogen Co. (Scotland, UK). Trichloroacetic acid (TCA) and Tris buffer were acquired from Merck (Darmstadt, Germany). SlowFade ${ }^{\circledR}$ Gold Antifade Mountant with DAPI and LysoTracker ${ }^{\circledR}$ Deep Red were purchased from Molecular Probes (Invitrogen Co., Scotland).

\section{Cell lines}

Three different human cell lines were used in this work. The two human pancreatic cell lines, hTERT-HPNE (hTERT immortalized human pancreatic nestin-expressing normal ductderived cells of the human pancreas) and S2-013 (well-differentiated tubular adenocarcinoma and moderately metastatic subline cloned from the human pancreatic tumor cell line SUIT2), were provided by Prof. M. A. Hollingsworth (UNMC, Nebraska, USA) [40,41]. The human lung cancer cell line, A549 (nonsmall cell lung carcinoma), [11] was kindly provided by Dr. Gabriela Almeida (IPATIMUP). For cell culture purposes, the cell lines were maintained in DMEM (for pancreatic cells) or RPMI (for lung cells) medium, supplemented with $10 \%$ fetal bovine serum (FBS) at $37{ }^{\circ} \mathrm{C}$ in a humidified $5 \% \mathrm{CO}_{2}$ incubator. When the cells reached $80 \%$ of confluence, they were trypsinized and subcultured.

\section{PLGA nanoparticle preparation}

PLGA NPs were prepared using the single emulsion solvent evaporation technique. For that purpose, $10 \mathrm{mg}$ of PLGA was dissolved in $0.1 \mathrm{~mL}$ of ethyl acetate, and for encapsulation, $1 \mathrm{mg}$ of vitamin was added. PLGA NPs for the entrapment of coumarin- 6 were also prepared by this method using $1 \% \mathrm{w} / \mathrm{w}$ of coumarin-6 (C6). $200 \mu \mathrm{L}$ of an aqueous solution of $1 \% \mathrm{w} / \mathrm{v}$ Pluronic ${ }^{\circledR} \mathrm{F} 127$ was added dropwise to the organic phase. Then, the solution was vortexed and emulsified by sonication at an ultrasonic frequency of $45 \mathrm{kHz}$. The emulsion was subsequently poured into $2.5 \mathrm{~mL}$ of $0.1 \% \mathrm{w} / \mathrm{v}$ Pluronic ${ }^{\circledR} \mathrm{F} 127$ and stirred $(800 \mathrm{rpm})$ at room temperature until complete evapor- 
ation of the organic solvent. The resulting suspension was filtered $(0.2 \mu \mathrm{m}$, Millex-GP Filter Units, Merck Millipore, Germany) and incubated at $4{ }^{\circ} \mathrm{C}$ overnight to increase the NP stability. Then, the NPs were collected by centrifugation (14500 rpm, $30 \mathrm{~min}$ ), and resuspended in ultrapure water. All formulations were prepared in triplicate.

Calcitriol-loaded PLGA NPs were freeze-dried to avoid the need to prepare particles whenever we conducted cell studies, and for the eventual future pharmaceutical applications. Lyophilization was carried out in a BenchTop ${ }^{\mathrm{TM}} \mathrm{K}$ series freeze-dryer (VirTis, NY, USA) at $5 \times 10^{-5}$ bar and $-95{ }^{\circ} \mathrm{C}$ for $48 \mathrm{~h}$.

\section{PLGA nanoparticle physicochemical characterization}

The size, polydispersity index (PDI), zeta potential, morphology, vitamin loading capacity and encapsulation efficiency were the parameters used to characterize the produced nanoparticles. The size distribution and zeta potential were determined by dynamic light scattering (DLS) and electrophoretic light scattering (ELS), respectively, using a ZetaSizer Nano ZS (Malvern Instruments, Worcestershire, UK). The size distribution was given by the PDI. DLS and ELS measurements were also performed to evaluate modifications in the PLGA NP size and zeta potential and possible particle aggregation over time under storage conditions (aqueous suspension stored at $4{ }^{\circ} \mathrm{C}$ ) and after freeze-drying. The effect of sucrose (at a concentration of $1 \% \mathrm{w} / \mathrm{v}$ ) used as a cryoprotective agent on the NPs stability during freeze-drying was also determined. The stability of the calcitriol in the NPs was evaluated by UV-vis spectrophotometry measurements after freeze-drying.

Unloaded and vitamin-loaded PLGA NPs were also analyzed for size and morphology by transmission electron microscopy (TEM) using a JEOL JEM 1400 microscope (Tokyo, Japan) at an accelerating voltage of $80 \mathrm{kV}$. The samples were deposited on copper grids (formvar/carbon on 400 mesh $\mathrm{Cu}$ from Agar Scientific) and negative-stained with $2 \% \mathrm{v} / \mathrm{v}$ uranyl acetate for $45 \mathrm{~s}$. The grids were air-dried prior to TEM visualization [42].

Vitamin loading capacity (LC) and the encapsulation efficiency (EE) of PLGA NPs were further indirectly determined. For the quantification of the free vitamin, the NP suspension was centrifuged (14500 rpm, $30 \mathrm{~min}$ ), and the supernatant analyzed. This step was conducted before organic solvent evaporation to ensure vitamin solubility. The sample was measured by UV-vis spectrophotometry at $265 \mathrm{~nm}$, using a UV-1700 PharmaSpec UV-vis spectrophotometer from Shimadzu (Japan). The results were inferred from a calibration curve of known vitamin concentrations. All experiments were performed in triplicate.

\section{In vitro release studies}

The in vitro release behavior of calcitriol entrapped in PLGA NPs was assessed over seven days. A sufficient amount of calcitriol-loaded PLGA NPs were resuspended in release buffer (PBS 0.01 M, pH 7.4) and divided into 7 aliquots. The aliquots were maintained at $37^{\circ} \mathrm{C}$ and at determined set time points, and each aliquot was centrifuged at $14500 \mathrm{rpm}$ for $30 \mathrm{~min}$. Amicon ${ }^{\circledR}$ Ultra- 0.5 centrifugal filter devices (Merck Millipore, Germany) were used to remove PLGA degradation products and NPs. The release medium was freeze-dried and further reconstituted with ethanol $100 \% \mathrm{v} / \mathrm{v}$ for measurement by UV-vis spectrophotometry at $265 \mathrm{~nm}$ and the amount of released calcitriol was calculated from the calibration curve in ethanol. A solution of calcitriol in PBS was used as control to assess the stability of calcitriol in the release conditions over the seven days. All experiments were performed in triplicate.

\section{Cellular imaging studies}

Laser scanning confocal microscopy (LSCM) was used to evaluate the NP in vitro uptake and morphological changes in S2-013, hTERT-HPNE and A549 cells. The cells were seeded in $\mu$-chamber 12 -well plates (ibidi, Germany) at a density of 1000 cells per well for $24 \mathrm{~h}$ prior to the experiment. This period, under normal conditions $\left(5 \% \mathrm{CO}_{2}\right.$ humidified atmosphere at $37^{\circ} \mathrm{C}$ ), allows cells to adhere. The cells were then treated with $2.4 \mu \mathrm{M}$ free calcitriol and entrapped calcitriol in C6-loaded PLGA NPs for 2 and $72 \mathrm{~h}$. The lipophilic fluorescent dye C6 entrapped in the NP matrix does not leach during the experiment, allowing a fluorescent visualization of the uptake of PLGA NPs [30]. After the incubation period, the cells were rinsed with $\mathrm{PBS}$ and fixed using 4\% paraformaldehyde for $15 \mathrm{~min}$. The cells were then treated with LysoTracker ${ }^{\circledR}$ Red (a marker of endo-lysosomal compartments) for $1 \mathrm{~h}$. The cells were washed with PBS and mounted on a glycerol-based medium with DAPI for nuclear staining. Acquisitions were performed with a Leica TCS SP5 II confocal laser scanning microscope (Leica Microsystems, Germany) in emission mode. Untreated cells were also imaged as control. Different areas were analyzed and at least six images were acquired for each type of cell. The ImageJ JACoP "colocalization finder" plug-in was used for the determination of the Pearson coefficient ( $r$ ), as a quantitative indicator of colocalization of the NPs in the lysosomes of cells.

\section{In vitro cytotoxicity studies}

The effects of the calcitriol-loaded PLGA nanoparticles and free calcitriol on the cell growth of different human cell lines were evaluated by sulforhodamine B (SRB). This colorimetric method allows an indirect estimation of cell number by measuring cellular protein content [43]. 
The experiments were performed in 96-well assay plates, where exponentially growing cells were seeded for an incubation period of $24 \mathrm{~h}$ at a density of 1000 cells per well before treatment with free calcitriol, blank PLGA NPs and calcitriol-loaded PLGA NPs. The NP samples and free calcitriol were diluted in cell culture medium at eight final concentrations of calcitriol ranging from 0.005 to $3.2 \mu \mathrm{M}$, and the cells were incubated with these samples for $48 \mathrm{~h}$ and $72 \mathrm{~h}$. A calcitriol stock solution of $3.2 \mathrm{mM}$ was prepared in ethanol to ensure calcitriol solubility, but all samples of calcitriol alone contained at most $0.1 \% \mathrm{v} / \mathrm{v}$ ethanol. Due to the short half-life of calcitriol in cell culture medium, the supplemented medium was renewed daily [44]. After the 48-72 $\mathrm{h}$ incubation period, the cytotoxic effect was assayed by SRB, in a similar manner as previously described in [30]. The cells were fixed with $10 \%$ TCA for $1 \mathrm{~h}$ at $4{ }^{\circ} \mathrm{C}$. The cell monolayers were then washed and stained with $50 \mu \mathrm{L} \mathrm{SRB}$ dye for $30 \mathrm{~min}$. The cells were subsequently washed repeatedly with $1 \%$ acetic acid to remove any unbound dye. The cells were air-dried and the protein-bound stain was solubilized with $10 \mathrm{mM}$ Tris solution. The SRB absorbance was measured at $560 \mathrm{~nm}$ using the PowerWave microplate reader (HT Microplate Spectrophotometer, BioTek). By comparing the measured absorbance of the wells containing the drug or the NPs with the measurements of the wells containing the untreated cells, it was possible to generate dose-response profiles and determine the concentration inhibiting the net cell growth by $50 \%\left(\mathrm{GI}_{50}\right)$. This step was perfomed following the incubation period, and subsequent comparison of these results with those obtained for cells that had been fixed at time zero (the time at which calcitriol/NPs were added).

Unloaded PLGA NPs and $0.1 \%$ of ethanol were added as a control to assess the effect on cell growth in control cells. Unexposed cells were also included in all assays as nontreatment controls (null controls). Two independent experiments were measured in triplicate.

\section{Cell cycle analysis}

The cell cycle analysis was conducted by flow cytometry (FCM). The cells were seeded in T75 flasks at a density of $1 \times 10^{5}$ cells $/ \mathrm{mL}$ for $24 \mathrm{~h}$ prior to the experiment. The cells were then treated with $1.2 \mu \mathrm{M}$ of free calcitriol and entrapped in PLGA NPs for $72 \mathrm{~h}$. Due to the short half-life of calcitriol in cell culture medium, the supplemented medium with free calcitriol was renewed daily. Untreated cells were also used as a control. To reduce the effects of contact inhibition, control cells were adjusted to reach $60-70 \%$ confluence at the time of FCM analysis. After the incubation period, the cells were harvested and fixed with $70 \% \mathrm{v} / \mathrm{v}$ ethanol. The cells were then stained with a DNA staining solution $(0.1 \% \mathrm{v} / \mathrm{v}$ TritonX-100, $20 \mu \mathrm{g} / \mathrm{mL}$ PI and $35 \mu \mathrm{g} / \mathrm{mL}$ of RNase A in PBS) at a cell density of $10^{6}$ cells $/ \mathrm{mL}$. FCM (FACSCalibur, BD Biosciences, CA, USA) was performed by plotting 12,000 gated events per sample. The data were subsequently analyzed by FlowJo 7.2 software (Tree Star, Ashland, USA). Three independent experiments were conducted.

\section{Statistical analysis}

Statistical analysis was performed by using a two-tailed Student's t-test, considering a 95\% confidence interval. p-values lower than 0.05 were considered significant.

\section{Acronyms}

\begin{tabular}{|c|c|}
\hline Term & Abbreviation \\
\hline drug delivery systems & DDS \\
\hline dynamic light scattering & DLS \\
\hline Dulbecco's Modified Eagle mMedium & DMEM \\
\hline encapsulation efficiency & EE \\
\hline electrophoretic light scattering & ELS \\
\hline enhanced permeability and retention effect & EPR effect \\
\hline fetal bovine serum & FBS \\
\hline flow cytometry & FCM \\
\hline Food and Drug Administration & FDA \\
\hline half maximal growth inhibitory concentration & $\mathrm{Gl}_{50}$ \\
\hline half maximal survival inhibitory concentration & $\mathrm{IC}_{50}$ \\
\hline loading capacity & LC \\
\hline laser scanning confocal microscopy & LSCM \\
\hline multidrug resistance & MDR \\
\hline nanoparticles & NPs \\
\hline phosphate buffered saline & PBS \\
\hline polydispersity index & PDI \\
\hline poly(glycolic acid) & PGA \\
\hline propidium iodide & $\mathrm{PI}$ \\
\hline poly(lactic acid) & PLA \\
\hline poly(lactic-co-glycolic acid) & PLGA \\
\hline Roswell Park Memorial Institute medium & RPMI \\
\hline sulforhodamine B & SRB \\
\hline trichloroacetic acid & TCA \\
\hline transmission electron microscopy & TEM \\
\hline ultraviolet-visible radiation & UV-vis \\
\hline vitamin $\mathrm{D}$ receptor & VDR \\
\hline
\end{tabular}

\section{Supporting Information}

\section{Supporting Information File 1}

Effects of calcitriol after $48 \mathrm{~h}$ and $72 \mathrm{~h}$ treatment on cell survival.

[http://www.beilstein-journals.org/bjnano/content/ supplementary/2190-4286-6-135-S1.pdf] 


\section{Acknowledgements}

This work was supported by Fundação para Ciência e Tecnologia (FCT, Portugal) trough research project PTDC/ QUI-BIQ/115449/2009. J. A. Loureiro acknowledges FEDER postdoctoral grant (NORTE-07-0124-FEDER-000025/FEUPON2-25MC-Eng ${ }^{\mathrm{a}}$ QuimicaBiologica). M. J. Ramalho and B. Gomes acknowledge FCT research grant (PTDC/QUI-BIQ/ 118076/2010). M. F. Frasco acknowledges FCT postdoctoral grant (SFRH/BPD/40876/2007). The authors thank Dr. Filipe Santos-Silva for the possibility to use the facilities of the Institute of Molecular Pathology and Immunology of the University of Porto (IPATIMUP, Porto, Portugal). We also acknowledge Prof. Michael A. Hollingsworth (University of Nebraska Medical Center, USA) and Gabriela Almeida (IPATIMUP) for kindly providing the cell lines.

\section{References}

1. Krishnan, A. V.; Feldman, D. Annu. Rev. Pharmacol. Toxicol. 2011, 51, 311-336. doi:10.1146/annurev-pharmtox-010510-100611

2. Trump, D. L.; Deeb, K. K.; Johnson, C. S. Cancer J. 2010, 16, 1-9. doi:10.1097/PPO.0b013e3181c51ee6

3. Glade, M. J. Nutrition 2013, 29, 37-41. doi:10.1016/j.nut.2012.05.010

4. Wang, Z.; Fan, J.; Liu, M.; Yeung, S.; Chang, A.; Chow, M. S.; Pon, D.; Huang, Y. Expert Opin. Invest. Drugs 2013, 22, 1613-1626. doi:10.1517/13543784.2013.833183

5. Guraya, S. Y. J. Microsc. Ultrastruct. 2014, 2, 1-6. doi:10.1016/j.jmau.2013.09.001

6. Colston, K.; Colston, M. J.; Fieldsteel, A. H.; Feldman, D. Cancer Res. 1982, 42, 856-859.

7. Kawa, S.; Nikaido, T.; Aoki, Y.; Zhai, Y.; Kumagai, T.; Furihata, K.; Fujii, S.; Kiyosawa, K. Br. J. Cancer 1997, 76, 884-889. doi:10.1038/bjc.1997.479

8. Khare, D.; Godbole, N. M.; Pawar, S. D.; Mohan, V.; Pandey, G.; Gupta, S.; Kumar, D.; Dhole, T. N.; Godbole, M. M. Eur. J. Nutr. 2013, 52, 1405-1415. doi:10.1007/s00394-012-0449-7

9. Kim, S. H.; Chen, G.; King, A. N.; Jeon, C. K.; Christensen, P. J.; Zhao, L.; Simpson, R. U.; Thomas, D. G.; Giordano, T. J.; Brenner, D. E.; Hollis, B.; Beer, D. G.; Ramnath, N. Lung Cancer 2012, 77, 265-271. doi:10.1016/j.lungcan.2012.04.010

10. Parise, R. A.; Egorin, M. J.; Kanterewicz, B.; Taimi, M.; Petkovich, M.; Lew, A. M.; Chuang, S. S.; Nichols, M.; El-Hefnawy, T.; Hershberger, P. A. Int. J. Cancer 2006, 119, 1819-1828. doi:10.1002/ijc.22058

11. Pelczynska, M.; Wietrzyk, J.; Jaroszewicz, I.; Nevozhay, D.; Switalska, M.; Kutner, A.; Zabel, M.; Opolski, A. Anticancer Res. 2005, 25, 2235-2240.

12. Schwartz, G. G.; Eads, D.; Rao, A.; Cramer, S. D.; Willingham, M. C.; Chen, T. C.; Jamieson, D. P.; Wang, L.; Burnstein, K. L.; Holick, M. F.; Koumenis, C. Carcinogenesis 2004, 25, 1015-1026. doi:10.1093/carcin/bgh086

13. Wolpin, B. M.; Ng, K.; Bao, Y.; Kraft, P.; Stampfer, M. J.; Michaud, D. S.; Ma, J.; Buring, J. E.; Sesso, H. D.; Lee, I. M.; Rifai, N.; Cochrane, B. B.; Wactawski-Wende, J.; Chlebowski, R. T.; Willett, W. C.; Manson, J. E.; Giovannucci, E. L.; Fuchs, C. S. Cancer Epidemiol., Biomarkers Prev. 2012, 21, 82-91. doi:10.1158/1055-9965.EPI-11-0836
14. Almouazen, E.; Bourgeois, S.; Jordheim, L. P.; Fessi, H.; Briançon, S. Pharm. Res. 2013, 30, 1137-1146. doi:10.1007/s11095-012-0949-4

15. Luo, Y.; Teng, Z.; Wang, Q. J. Agric. Food Chem. 2012, 60, 836-843. doi:10.1021/jf204194z

16. Yin, L.; Grandi, N.; Raum, E.; Haug, U.; Arndt, V.; Brenner, H. Eur. J. Cancer 2010, 46, 2196-2205.

17. Plum, L. A.; DeLuca, H. F. Nat. Rev. Drug Discovery 2010, 9, 941-955. doi:10.1038/nrd3318

18. Acharya, S.; Sahoo, S. K. Adv. Drug Delivery Rev. 2011, 63, 170-183. doi:10.1016/j.addr.2010.10.008

19. Kumari, A.; Yadav, S. K.; Yadav, S. C. Colloids Surf., B 2010, 75, 1-18. doi:10.1016/j.colsurfb.2009.09.001

20. Danhier, F.; Ansorena, E.; Silva, J. M.; Coco, R.; Le Breton, A.; Préat, V. J. Controlled Release 2012, 161, 505-522. doi:10.1016/j.jconrel.2012.01.043

21. Steichen, S. D.; Caldorera-Moore, M.; Peppas, N. A. Eur. J. Pharm. Sci. 2013, 48, 416-427. doi:10.1016/j.ejps.2012.12.006

22. Nguyen, T. L. U.; Tey, S. Y.; Pourgholami, M. H.; Morris, D. L.; Davis, T. P.; Barner-Kowollik, C.; Stenzel, M. H. Eur. Polym. J. 2007, 43, 1754-1767. doi:10.1016/j.eurpolymj.2007.02.019

23. Bonor, J. C.; Schaefer, R. J.; Menegazzo, N.; Booksh, K.; Nohe, A. G. J. Nanosci. Nanotechnol. 2012, 12, 2185-2191. doi:10.1166/jnn.2012.5785

24. Bolte, S.; Cordeliéres, F. P. J. J. Microsc. (Oxford, U. K.) 2006, 224, 213-232. doi:10.1111/j.1365-2818.2006.01706.x

25. Guelluy, P.-H.; Fontaine-Aupart, M.-P.; Grammenos, A.; Lécart, S.; Piette, J.; Hoebeke, M. Photochem. Photobiol. Sci. 2010, 9, 1252-1260. doi:10.1039/c0pp00100g

26. Yoshizawa-Sugata, N.; Masai, H. Cell Cycle Synchronization and Flow Cytometry Analysis of Mammalian Cells. In Cell Cycle Control; Noguchi, E.; Gadaleta, M. C., Eds.; Methods in Molecular Biology, Vol. 1170; Springer: New York, NY, U.S.A., 2014; pp 279-293. doi:10.1007/978-1-4939-0888-2_13

27. Henry, C. M.; Hollville, E.; Martin, S. J. Methods 2013, 61, 90-97. doi:10.1016/j.ymeth.2013.01.008

28. Musumeci, T.; Ventura, C. A.; Giannone, I.; Ruozi, B.; Montenegro, L.; Pignatello, R.; Puglisi, G. Int. J. Pharm. 2006, 325, 172-179. doi:10.1016/j.ijpharm.2006.06.023

29. Wilczewska, A. Z.; Niemirowicz, K.; Markiewicz, K. H.; Car, H. Pharmacol. Rep. 2012, 64, 1020-1037. doi:10.1016/S1734-1140(12)70901-5

30. Frasco, M. F.; Almeida, G. M.; Santos-Silva, F.; Pereira, M. d. C.; Coelho, M. A. N. J. Biomed. Mater. Res., Part A 2015, 103, 1476-1484. doi:10.1002/jbm.a.35286

31. Holzer, M.; Vogel, V.; Mäntele, W.; Schwartz, D.; Haase, W.; Langer, K. Eur. J. Pharm. Biopharm. 2009, 72, 428-437. doi:10.1016/j.ejpb.2009.02.002

32. Wischke, C.; Schwendeman, S. P. Int. J. Pharm. 2008, 364, 298-327. doi:10.1016/j.ijpharm.2008.04.042

33. Anderson, J. M.; Shive, M. S. Adv. Drug Delivery Rev. 2012, 64, 72-82. doi:10.1016/j.addr.2012.09.004

34. Tahara, K.; Sakai, T.; Yamamoto, H.; Takeuchi, H.; Hirashima, N.; Kawashima, Y. Int. J. Pharm. 2009, 382, 198-204. doi:10.1016/j.jpharm.2009.07.023

35. Kunjachan, S.; Rychlik, B.; Storm, G.; Kiessling, F.; Lammers, T. Adv. Drug Delivery Rev. 2013, 65, 1852-1865. doi:10.1016/j.addr.2013.09.018

36. Artaza, J. N.; Sirad, F.; Ferrini, M. G.; Norris, K. C. J. Steroid Biochem. Mol. Biol. 2010, 119, 73-83. doi:10.1016/j.jsbmb.2010.01.001 
37. González-Pardo, V.; Suares, A.; Verstuyf, A.; De Clercq, P.; Boland, R.; de Boland, A. R. J. Steroid Biochem. Mol. Biol. 2014, 144 , 197-200. doi:10.1016/j.jsbmb.2013.11.014

38. Campisi, J. Annu. Rev. Physiol. 2013, 75, 685-705. doi:10.1146/annurev-physiol-030212-183653

39. Axanova, L. S.; Chen, Y. Q.; McCoy, T.; Sui, G.; Cramer, S. D. Prostate 2010, 70, 1658-1671. doi:10.1002/pros.21201

40. Lee, K. M.; Yasuda, H.; Hollingsworth, M. A.; Ouellette, M. M. Lab. Invest. 2005, 85, 1003-1012. doi:10.1038/labinvest.3700298

41. Iwamura, T.; Caffrey, T. C.; Kitamura, N.; Yamanari, H.; Setoguchi, T.; Hollingsworth, M. A. Cancer Res. 1997, 57, 1206-1212.

42. Parveen, S.; Sahoo, S. K. Eur. J. Pharmacol. 2011, 670, 372-383. doi:10.1016/j.ejphar.2011.09.023

43. Skehan, P.; Storeng, R.; Scudiero, D.; Monks, A.; McMahon, J.; Vistica, D.; Warren, J. T.; Bokesch, H.; Kenney, S.; Boyd, M. R. J. Natl. Cancer Inst. 1990, 82, 1107-1112. doi:10.1093/jnci/82.13.1107

44. Wagner, N.; Wagner, K.-D.; Schley, G.; Badiali, L.; Theres, H.; Scholz, H. Exp. Eye Res. 2003, 77, 1-9. doi:10.1016/S0014-4835(03)00108-8

\section{License and Terms}

This is an Open Access article under the terms of the Creative Commons Attribution License

(http://creativecommons.org/licenses/by/2.0), which permits unrestricted use, distribution, and reproduction in any medium, provided the original work is properly cited.

The license is subject to the Beilstein Journal of

Nanotechnology terms and conditions:

(http://www.beilstein-journals.org/bjnano)

The definitive version of this article is the electronic one which can be found at: doi:10.3762/bjnano.6.135 